\title{
Cerium oxide ISFET based immune biosensor for control of bacterial contamination
}

\author{
Nickolaj F. Starodub, Julia O. Ogorodnijchuk \\ National University of Life and Environmental Sciences of Ukraine, Gerojev Oborony Str. 15, Kiev, \\ Ukraine \\ nikstarodub@yahoo.com
}

\begin{abstract}
A new cerium oxide ISFET based immune biosensor for the determination of Salmonella in solution was developed. It was chosen "sandwich" algorithm of analysis when one part of specific antibodies was immobilized on the transducer surface and other one labeled by the horse radish peroxidase (HRP) was added to analyzed solution. Overall time of analysis was about 15-20 min. The maximal sensitivity of $S$. typhimurium determination in model solutions was on the level of 2-3 cells $\mathrm{ml}^{-1}$ with the linearity of the immune biosensor response up to $5 \times 10^{5}$ cells $\mathrm{ml}^{-1}$.
\end{abstract}

Key words: immune biosensor, CeOx gate surface, Salmonella typhimurium, determination, model solutions

\section{Introduction}

The traditional methods for the control of contamination by Salmonella, Trichinella and others pathogenic microorganisms are extremely routine and performance of them is rather routine, expensive and requires the use of the stationary equipments and high professional level $[1,2]$. To overcome these shortcomings, at least at the stage of screening or of purely serological testing we believe that it is appropriate to use modern methods of biosensors. A number of different types of biosensors based on surface plasmon resonance (SPR), total internal reflection ellipsometry (TIRE), quartz crystal acoustic wave, amperometry, chemiluminescence and PCR-genosensor were proposed [3-10]. Previously [9-11], we have developed the optical immune biosensors based on the SPR and TIRE. The linear diapason of the detection of $S$. typhimurium by SPR based immune biosensor is $2 \times 10^{2}-10^{7}$ cells $/ \mathrm{mL}$ and the sensitivity of the analysis by the TIRE immune biosensor achieves up to 5 cells $/ 10 \mathrm{ml}$. Both approaches may be fulfilled by the "direct" way when the specific antibodies immobilized on the transducer surface preliminary treated by polyalylamine hydrochloride and protein $A$ react with the $S$. typhimurium being in model solution. The similar results were obtained and other authors $[3,7,8,12-17]$ which used the "Biocore" device. However, infection dose of pathogenic microorganisms is less than 10 cells per $100 \mathrm{ml}$ [18] therefore it is necessary to find ways for the sensitivity increasing. Perhaps, satisfactory result can be obtained using monoclonal antibodies. Also it is necessary to pay attention to the effective methods of previous food samples preparation especially to the methods of bacteria cells concentration in the solution. On the other hand it should be emphasized that the above mentioned biosensors require fairly sophisticated and expensive equipment for the registration of the formed immune complex. In this case the application of the electrochemical biosensors may help to overcome this lack. In particular it may be achieved with the help immune biosensor based on the ISFETs. We have developed this type of biosensors for the control of some biochemical quantities $[19,20]$ and toxic substances [21, 22]. Early [22] we used nitride oxide ISFETs in immune biosensors intended for the control of some biochemical quantitives, pesticides and mycotoxins. To increase the sensitivity and stability of such type biosensor we have proposed to replace silicon nitrate to cerium oxide on the transducer surface [23, 24]. The main purpose of this report is to demonstrate the abilities of the cerium oxide ISFETs at its application for the development of immune biosensor for determination of $S$. typhimurium in the model solutions. 


\section{Experimental}

ISFETs were produced by Prof. A.N. Shmyryeva in the National Technical University of "Kiev Polytechnical Institute". $\mathrm{CeO}_{\mathrm{x}}$ layer was fabricated by method of "oxidization of metallic mirror" with the electron beam evaporation. The chamber pressure was $10^{-5} \mathrm{~Pa}$, the emission current - equal to $140 \mathrm{~mA}$, accelerating voltage - $12 \mathrm{kV}$, substrate temperature - in the range $170 \div 180^{\circ} \mathrm{C}$. Oxidation of cerium was carried out in a diffusion furnace at $250{ }^{\circ} \mathrm{C}$ in oxygen. It was investigated the ISFETs with two types of insulators: $\mathrm{SiO}_{2}-\mathrm{Si}_{3} \mathrm{~N}_{4}, \mathrm{~d}_{\mathrm{Si} 3 \mathrm{~N} 4}=50 \mathrm{~nm}$ and $\mathrm{CeO}_{2} \mathrm{~d}_{\mathrm{CeO} 2}=50 \mathrm{~nm}$. The measurements were performed at the room temperature and atmospheric pressure. To measure $\mathrm{pH}$ sensitivity using atandard buffer solutions with value from 12,45 up to 1,68 . The design parameters of ISFETs were studied by methods of optical and scanning microscopy.ISFET surface was cleaned by its sequential immersion into the mixture of potassium dichromate and sulfuric acid, water, acetone, ethanol and phosphate Na-phosphate buffer (PB), pH 7.3, contained $100 \mathrm{mM} \mathrm{NaCl}$. Then, it was treated by water solution of cystamine, glutaraldehyde (GA) and protein A from Staphylococcus aureus. At last, the working chip was covered by specific antiserum and the reference one - by non-specific antiserum. Analysis was fulfilled by the "sandwich" way when the immobilized specific antibodies interact with Salmonella. Then, bounded cells on the transducer surface were treated by the specific antibodies labeled by HRP which activity was registered [25].

\section{Results and discussion}

Any surface oxide always contains hydroxyl groups. In case of $\mathrm{CeO}_{x}$ the changes of surface charge at the variation of $\mathrm{pH}$ arise due to $\mathrm{CeOH}$ groups. Between protons in solution and hydroxyl groups formed on the boundary of $\mathrm{CeO}_{2}$-solution the equilibrium reactions have place. The hydrogen proton concentration may be determined according to shift of the threshold voltage of ISFET or to change the drain current in the transistor channel. The experimental characteristics of the studied ISFETs are presented in Fig. 1.

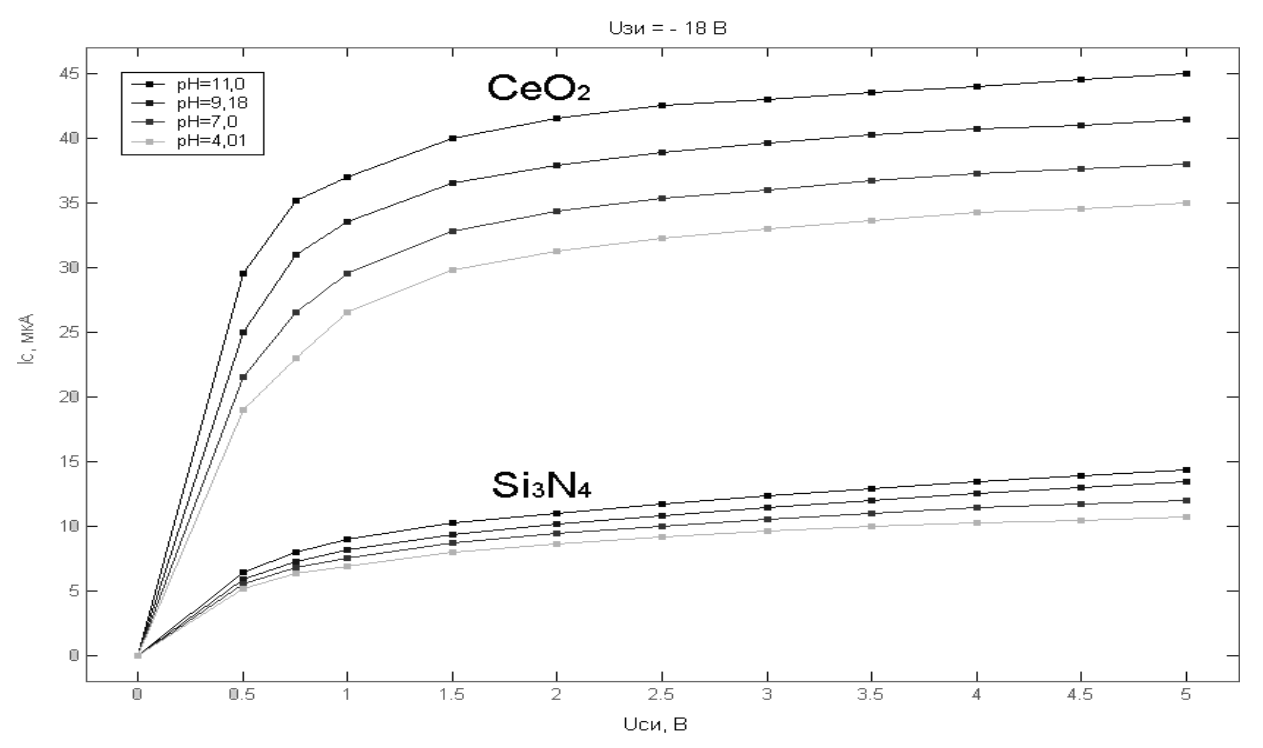

Fig. 1. Influence of $\mathrm{pH}$ on the output characteristics of ISFETs with the $\mathrm{Si}_{3} \mathrm{~N}_{4}$ and $\mathrm{CeO}_{2}$ dielectric structures.

At the $\mathrm{pH}$ increasing of solution the value of positive charge on the surface of ion-sensitive dielectric is decreased. Since we used $p$ channel ISFETs the decreasing of positive charge on the dielectric surface leads to increasing in channel conductance and hence to increase the drain current for both structures $\mathrm{SiO}_{2}-\mathrm{Si}_{3} \mathrm{~N}_{4}$ and $\mathrm{SiO}_{2}-\mathrm{CeO}_{2}$. It was shown that the most linear and stable responses for both dielectric structures were registered at the voltage in $10 \mathrm{~V}$. The same they had linear character of dependence on $\mathrm{pH}$ changes (for $\mathrm{SiO}_{2}-\mathrm{Si}_{3} \mathrm{~N}_{4}-63 \mathrm{mV} / \mathrm{pH}$ and for $\mathrm{CeO}_{2}-58$ $\mathrm{mV} / \mathrm{pH}$ ). The sensitivity of current flow due to the large dielectric constant of cerium oxide was increased more than two times $(\varepsilon=26)$.

When the concentrations of the HRP-specific antibodies were varied in the range $0.1-0.4 \mu \mathrm{g}$ per $\mathrm{ml}^{-1}$ it was found that the maximal sensor output (about $100 \mathrm{mV}$ ) corresponded to $0.2 \mu \mathrm{g}$ $\mathrm{ml}^{-1}$ of the conjugate. Under these conditions 
binding sites of the specific antibodies were saturated. In the range of Salmonella concentrations from 2 to $5 \times 10^{5}$ cells $\mathrm{ml}^{-1}$ the ISFET gate varied from 95 to $5 \mathrm{mV}$ (Fig 2). The standard deviation was in average about $5 \%$. When transducer surface was preliminary prepared the overall time of the assay was about 30 min. It may be shortened in two times, in particular, at the concentration of Salmonella cells in $10 \mathrm{ml}^{-1}$ and higher. Another approach to short time of analysis even at the minimal concentrations of Salmonella is preliminary introduction of the specific HRP labeled antibodies into solution to be analyzed. Our experiments have shown that the time of the analysis may be about $15-20$ min only without any changes in the value of biosensor response and the sensitivity of analysis. Destruction of antigen-antibody bonds by treatment of the chips with $0.1 \mathrm{M} \mathrm{HCl}$ for 5 min made possible to reuse the chips for several measurements (up to 5) without signal decrease. Between the measurements chips were stored in dry state at $4{ }^{\circ} \mathrm{C}$. Before every new assay they were washed with PB for $1 \mathrm{~h}$.

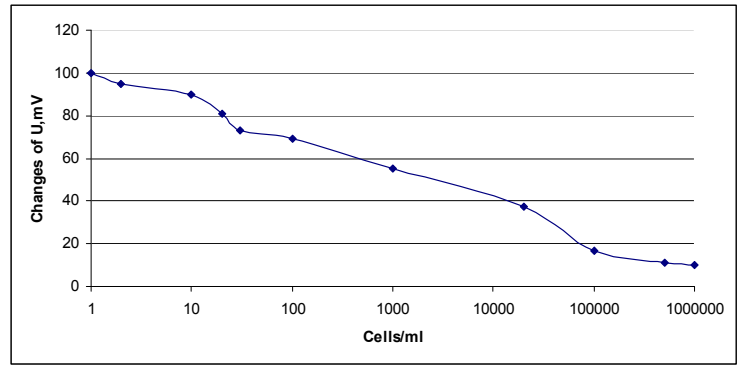

Fig. 2. Immune biosensor response at the different concentration of Salmonella in the model solution.

It is necessary to mention a high reproducibility of results between different measurements by individual ISFETs. To achieve such reproducibility we used the gate surface in ISFETs in form of CeOx instead of $\mathrm{Si}_{3} \mathrm{~N}_{4}$. Moreover, both the electrical characteristics of the transducer and the procedure for biological membrane preparation were standardized. In the letter case, it was very important to fulfill exactly the protocol of cleaning and activation of gate surface as well as to provide constant humid conditions during the recommended time of interaction of the protein A with the activated groups of the gate surface.

We analyzed the non-specific responses to addition of the work buffer (WB) or hydrogen peroxide. For this purpose, a differential scheme was used: the one of ISFET contained specific antibodies immobilized via protein $A$, the second had non-specific proteins from human serum blood immobilized via GA. It was shown (Fig. 3) that the WB did not influence on the biosensor output, while hydrogen peroxide in the concentration mentioned above $(10 \mathrm{mM})$ initiated small $(<10 \mathrm{mM})$ responses. $\mathrm{H}_{2} \mathrm{O}_{2}$ caused acidic $\mathrm{pH}$ shift in constant to the basic changes during the determination of the HRP activity. Thus neither WB nor $\mathrm{H}_{2} \mathrm{O}_{2}$ contributed to the biosensors basic $\mathrm{pH}$ shifts during the salmonella recording.

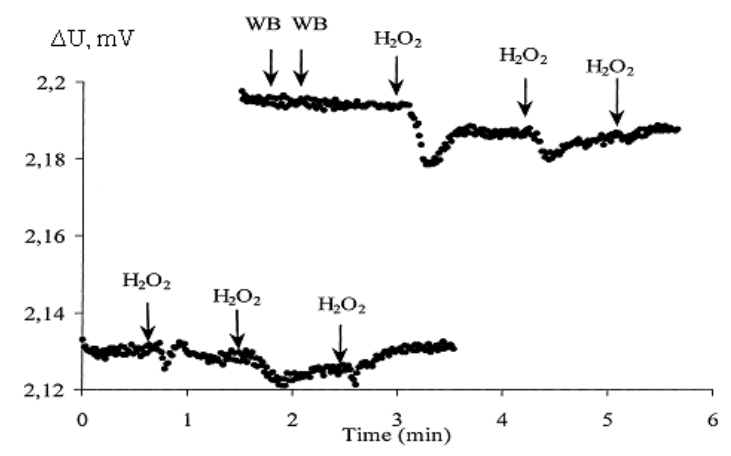

Fig. 3. Non-specific sensor response at the addition of $\mathrm{H} 2 \mathrm{O} 2$ and buffer. The ISFET potential is recorded as a function of time.

The study of the optimal concentration of hydrogen peroxide indicated that the immune biosensor output was about $15-20 \%$ higher for $10 \mathrm{mM}$ of $\mathrm{H}_{2} \mathrm{O}_{2}$ than $5 \mathrm{mM}$ of $\mathrm{H}_{2} \mathrm{O}_{2}$.

The comparison of our data about the determination of $\mathrm{S}$. typhimurium in model solution obtained by the optical immune biosensors and by the developed immune biosensor based on the ISFETs is shown that they are very close in the respect of the sensitivity (Table). So, the sensitivity of the analysis by the surface plasmon resonance (SPR) immune biosensor is $10^{1}$ cells $/ \mathrm{mL}$, or 5 cells $/ 10 \mathrm{ml}$ and linear field - in range $10^{1}-10^{7}$ cells $/ \mathrm{mL}$. The overall time of analysis is no more $30 \mathrm{~min}$, total internal reflection ellipsometry (TIRE) based biosensor allows having the sensitivity up to 5 cells per $10 \mathrm{ml}$.

The above-mentioned characteristics are in good correlation with other approaches published in the literature. But this sensitivity is not sufficient for all practice situations and subsequent work will be devoted to increase it. As it was shown early there is necessary to avoid especial attention to the procedures of sample preparations for analysis. They should include a number of steps: obtaining of quantitative extract from sample to be analyzed (in particular, if it is solid-state substance) and providing pre-enrichment of the obtained extract bacteria, which are amenable to definition. The last step is very important since it can give possibility to achieve the desired sensitivity analysis for practice. This situation can be successfully resolved through pre-use express bioaffine column chromatography. The 
combination of immune biosensor analysis with preliminary application of such chromatography will be as the basis for the fulfillment of very rapid, simple analysis with the sensitivity according practice demands. There is necessary to underline that the application of the ISFETs as transducers and the electrochemical registration of signal are most suitable approach in the respect of the creation of the immune biosensor which can provide low cost analysis in the comparison with that which may be provided by the optical ones based on the SPR and TIRE.

\section{Conclusion}

The comparison of the characteristics of the immune biosensors based on the SPR, TIRE, quartz crystal acoustic wave, amperometry, chemiluminescence [3-10] and on the ISFETs with $\mathrm{CeOx}$ gate surface testifies that they have similar sensitivity but the last approach may provide to achieve low cost of analysis. To have the sensitivity of analysis of bacteria on the level of infection dose, maybe, there is necessary to have a special system of the analyzed sample preparation, in particular, accumulation of cells through application of bioaffinic columns.

\section{References}

[1] Zarizkij A.M. Salmonellosis. K.: Zdorov'ja 3, 160 (1988)

[2] Laboratory diagnostics of salmonellosis, detection of salmonellas in foods and environment. Methodical Guidance, MG 2.272510, M, 49 (2010)

[3] S.T. Pathirana, J. Barbaree, B.A. Chin, M.G. Hartell, W.C. Neely, V. Vodyanoy Biosensors and Bioelectronics 15, 135-141 (2000)

[4] L. Croci, G. Palleschi, Anal. Lett., 34(15), $2597-$ 2607 (2001)

[5] O.A. Sadik, W.H. Land, J. Wang, Electroanalysis 15 (14), 1149-1159 (2003)

[6] M.J. Pividori, A. Mercoci, J. Barbe, S. Alegret Electroanalysis 15 (23-24), 1815-1823 (2003)

[7] [7] Y.Y. Wong, S.P. Ng, N.H. Ng, S.H. Si, S.Z. Yao, Y.S. Fung, Biosensors and Bioelectronics 17, 676-684 (2002)

[8] V. Koubova, E. Brynda, L. Karasova, J. SÏkvorc, J. Homola, J. Dostalek, P. Tobisïka, J. Rosïicky Sensors and Actuators B74, 100-105 (2001)

[9] N.F. Starodub, Ju.O. Ogorodnijchuk, V.O. Romanov, I.B. Galeljuka, I.M. Kushnir, Sci. Bull. 151 (2), 183-189 (2010)
[10] N.F. Starodub, Ju.A. Ogorodnijchuk, V. O. Romanov, In Book: "The Sensor+Test 2011 Conference”, 139-144 (2011)

[11] N.F. Starodub, lu.A. Ogorodniichuk, Ju. Sitnik, Express and simple instrumrntal control of foodborne toxins, viral and microbial infection agents, Abstract book of NATO ARW, 15 (2011)

[12] B. D. Spangler, E. A. Wilkinson, J. T. Murphy, B. J. Tyler, Anal. Chim. Acta 444, 149-161 (2001)

[13] B.K. Oh, Y.K. Kim, K.W. Park, W.H. Lee, J.W. Choi, Biosensors and Bioelectronics 19, 14971504 (2004)

[14] C.A. Gertie, M. Bokken, R.J. Corbee, F.van Knapen, A. A. Bergwerff, Journal FEMS Microbiology Letters 222, 75 - 82 (2003)

[15] J. R. Son, G. Kim, A. Kothapalli, M.T. Morgan, D. Ess, Detection of Salmonella enteritidis using a miniature optical surface Plasmon resonance biosensor, Journal Physics 61, 1086-1090 (2007)

[16] Lan Yu-bin, Wang Shi-zhou, Yin Yong-guang, Hoffmann W. Clint and Zheng Xian-zhe, J. of Bionic Engineering 5 (3), 239-246 (2008)

[17] T.M. Chinowsky, J.G. Quinn, D.U. Bartholomew, R. Kaiser, J.L. Elkind, Sensors and Actuators B91, 266-274 (2003)

[18] D. Ivnitski, I. Abdel-Hamid, P. Atanasov, E. Wilkins, Biosensors and Bioelectronics 14, 599624 (1999)

[19] N.F. Starodub, T.L. Dibrova, Yu.M. Shirshov, K.V. Kostjukevich, Ukr. Biochem Journal 71 (2), 33-37 (1999)

[20] Y.I. Korpan, A.P. Soldatkin, N.F. Starodub, A.V. El'skaya, M.V. Gonchar, A.A. Sibirny, A.A. Shul'ga, Anal. Chim. Acta 271, 203-208 (1993)

[21] N.F. Starodub, A.V. El'skaja, V. Polomarchuk, A.K. Sandrovsky, A.P. Soldatkin, V.I. Strikha, O.S. Frolov, L.N. Chustochka, A.A. Shul'ga, Electrochemistry 25 (5), 674-675 (1989)

[22] N.F. Starodub, B.B. Dzantiev, V.M. Starodub, A.V. Zherdev, Anal. Chim. Acta 424 (22), 37-43 (2000)

[23] N.F. Starodub, A. N. Shmiryeva, Immuneenzymatig biosensors based on the oxide cerium isfets: some physical and functional characteristics at the determination of somazine and T2-mycotoxin, In Book: "The SENSOR+TEST 2011 Conference”, 680-685 (2011)

[24] N.F. Starodub, O. M. Brezvin, Immune biosensor based on the oxide cerium IsFETs for the determination of mycotoxin level in environmental objects, In Book "LabAutomation 2011", 65 (2011)

[25] N.F. Starodub, O.E. Rachkov, A.V. Petik, G.V. Turkovskaja, N. I. Shul'ga, D.I. Balkov, In Proc. "Methods of Mol. Biol., 90-99 (1986) 